\title{
Development of Supply and Demand Functions of Pakistan's Wheat Crop
}

\author{
Muhammad Zulfiqar" and Anwar F. Chishti**
}

\begin{abstract}
A simultaneous-equations model was used to capture the supply and demand functions for Pakistan's wheat sector at the national level. This model reflects the fact that Pakistan's domestic wheat supply is priceresponsive and positively affected by the use of nutrient fertilizers. While price appears to be a statistically significant factor on the supply side, it is statistically insignificant on the demand side. Population size appears to be very significant in determining wheat demand. The wheat import supply seems to be influenced by the current world wheat price, current world wheat supplies, Pakistan's domestic consumption in previous years, and domestic supply in previous years. We recommend that policymakers allow market forces to play a role in the wheat economy in a way that protects producers from adverse market conditions. The availability of various nutrient fertilizers should be central to policies on future inputs use. Work is also needed on wheat alternatives so that the country's dependence on wheat is eased as much as possible.
\end{abstract}

Keywords: Wheat, supply and demand, Pakistan.

JEL Classification: C59, Q11.

\section{Introduction}

The wheat crop occupies a vital position in Pakistan's agrarian economy. Its share in terms of percentage area under major crops has remained around $36 \%$ for the last three decades (Agricultural Statistics of Pakistan). The production of the wheat crop in Pakistan is handled by private producers, but its marketing and trade have mainly been regulated by the government through 'support price' policies announced by the Government of Pakistan at the beginning of each cropping season. According to economic theory, the announcement of 'support or

\footnotetext{
* Director Planning, Kohat University of Science and Technology, Kohat, Pakistan.

** Dean, Management Sciences, Muhammad Ali Jinnah University, Islamabad, Pakistan.
} 
procurement prices' at the time of wheat sowing, the practice of wheat procurement, and the size of wheat stocks procured positively affect the area under wheat production and level of wheat production.

Despite the fact that the wheat crop contributes significantly toward the economy of Pakistan, there has been little analytical research carried out on its supply and demand determinants, with the exception of some research on the cost of production, supply response, and demand elasticities. Even studies carried out on cost, supply, and demand do not provide a complete picture; for instance, most of the studies carried out on the cost of production provide different estimates for the same crop and year due mainly to over- or underestimation (Arifullah, 2007). Studies on supply response in Pakistan include Falcon (1964), Cumming (1975), Tweeten (1986), Ahmad and Chaudry (1987), and Ali (1988). However, these studies do not provide econometrically estimated full production or supply functions, which are expected to reflect the major determinants of supply. On the demand side, fewer studies are available; these include Cornelisse and Kuijpers (1987), Ahmad, et al. (1987), Hamid, et al. (1987), Alderman (1988), and Ashfaq, Griffith, and Parton (2001).

For quantitative and analytical research, one needs at least four econometrically estimated supply and demand functions (domestic supply, domestic demand, export or import supply, and export or import demand functions). Since little systematic research work has been carried out on the development of econometrically estimated functions, there have been few mentionable research studies on price and policy analysis, government interventions, and associated welfare effects.

The aforementioned discussion necessitates carrying out a comprehensive research study of Pakistan's wheat crop with the objective of developing supply and demand functions that will facilitate policymakers in evaluating government interventions and improving resource use efficiency in wheat crop production.

\section{Material and Methods}

\section{Econometric Model}

This section presents a methodological and analytical framework for carrying out the research at hand. The following general model of supply and demand was specified.

$$
\mathrm{A}=\alpha_{0}+\alpha_{1} \mathrm{~A}_{\mathrm{t}-1}+\alpha_{2} \mathrm{P}_{\mathrm{d}}
$$




$$
\begin{aligned}
& \mathrm{S}_{\mathrm{d}}=\beta_{0}+\beta_{1} \hat{\mathrm{A}}+\beta_{2} \mathrm{FNT}+\beta_{3} \mathrm{PPT}+\beta_{4} \text { WAT } \\
& \mathrm{D}_{\mathrm{d}}=\gamma_{0}-\gamma_{1} \mathrm{P}_{\mathrm{d}}+\gamma_{2} \mathrm{GDPP}+\gamma_{3} \mathrm{POPP} \\
& \mathrm{I}_{\mathrm{d}}=\mathrm{D}_{\mathrm{d}}-\mathrm{S}_{\mathrm{d}} \\
& \mathrm{I}_{\mathrm{s}}=\theta_{0}+\theta_{1} \mathrm{P}_{\mathrm{i}}-\theta_{2} \mathrm{P}_{\mathrm{w}}+\theta_{2} \mathrm{~S}_{\mathrm{w}}
\end{aligned}
$$

The definitions of the various variables included in the model are provided in Table-1. The aforementioned model of supply and demand is a simultaneous-equations recursive model occurs in Gujarati (2003, pp.764-766) and Maddala (2002, p.373). A number of different specifications of this model were tried, and the final estimated model was selected on the basis of economic theory and statistical/econometric diagnostics using $\mathrm{R}^{2}$, F-test, t-test, Jarque-Bera (JB) Normality Test, DW test and Durban h tests (Zulfiqar, 2008).

\section{Data and Data Sources}

The model of wheat supply and demand functions specified above includes a number of dependent and explanatory variables: these include area and lagged area under wheat crop, domestic wholesale price for wheat, quantity supplied and demanded, quantity imported and import price, world average trade price, major inputs such as nutrient-fertilizers, pesticides and water used, gross domestic product (GDP) and population.

Data on most of the listed variables were downloaded from the FAO's website (www.fao.org; statistical databases). In addition, data were also obtained from the Government of Pakistan's Agricultural Statistics of Pakistan, and the UN COMTRADE database. GDP-related data were obtained from the IMF website. For estimation, time series data for the period $1979 / 80$ to $2004 / 05$ were used.

\section{Empirical Results}

After trying a number of different specifications of the mode1 specified in 1 (a-e), we ended up with the final estimated model given in Table-2. The various equations of this model are evaluated as follows.

\section{Wheat Acreage Equation}

The estimated wheat-acreage equation $\left(\mathrm{A}=3695.163+0.48947 \mathrm{~A}_{\mathrm{t}-1}\right.$ $+24.985 \mathrm{TR})$ fulfills all necessary diagnostic statistics; the explanatory variables included are in line with economic theory and are statistically 
significant. The lagged area $\left(\mathrm{A}_{\mathrm{t}-1}\right)$ positively determines the present acreage under wheat crop. The equation, however, seems to suffer from the problem of autocorrelation. As an autoregressive equation, DW is not valid and Durban $h$ is -2.0996 , which for no autocorrelation should fall in the interval 1.96 .

\section{Domestic Wheat Supply Equation}

The estimated domestic wheat supply equation $\left(\mathrm{S}_{\mathrm{d}}=-8458.219+\right.$ $2.4879 \hat{\mathrm{A}}+0.41528 \mathrm{P}_{\mathrm{d}}+2.4625 \mathrm{FNTW}$ ) ) reflects that the area predicted ( $\left.\hat{\mathrm{A}}\right)$ in an earlier equation along with the wholesale wheat price $\left(P_{d}\right)$ and nutrient fertilizers (FNTW'T) used determines the domestic production/supply of wheat in Pakistan.

\section{Domestic Wheat Demand Equation}

The domestic wheat demand equation $\left(\mathrm{D}_{\mathrm{d}}=750.129-0.046974 \mathrm{P}_{\mathrm{d}}+\right.$ 136.07POP) indicates that, as per economic theory, the domestic demand for wheat is negatively influenced by wheat wholesale prices and positively by the size of Pakistan's population (POP). The size of population is statistically significant at $\alpha=0.05$ while the price of wheat, although it carries the correct sign, is statistically insignificant. The latter results are acceptable in a situation where wheat is a major item of daily consumption, as in Pakistan. It is worth noting that price is one of the major and statistically significant determinants of wheat supply in Pakistan, as reflected by the earlier explained domestic wheat supply equation.

\section{Wheat Import Price Equation}

The estimated wheat import price equation $\left(P_{i}=23.1559+\right.$ $0.91124 \mathrm{P}_{\mathrm{w}}$ ) shows that Pakistan's import price is positively determined by the world wheat price.

\section{Wheat Import Supply Equation}

The estimated wheat import supply to Pakistan $\left(\mathrm{I}_{\mathrm{s}}=-5642.2+\right.$ $\left.5.2191 \mathrm{P}_{\mathrm{i}}^{\wedge}-0.96151 \mathrm{~S}_{\mathrm{d}, \mathrm{t}-1}+0.68329 \mathrm{D}_{\mathrm{d}, \mathrm{t}-1}+0.017019 \mathrm{~S}_{\mathrm{w}}\right)$ seems to have been positively affected by Pakistan's import price $\left(\mathrm{P}^{\wedge}\right.$; ; already determined in the last equation), the world supply of wheat $\left(\mathrm{S}_{\mathrm{w}}\right)$, and previous years' wheat consumption $\left(\mathrm{D}_{\mathrm{d}, \mathrm{t}-1}\right)$, and negatively by previous years' wheat supply $\left(\mathrm{S}_{\mathrm{d}, \mathrm{t}-\mathrm{l}}\right)$. 


\section{Conversion to an Easy-to-Use Model}

\section{Conversion Procedure}

The econometrically estimated model of Pakistan's wheat supply and demand functions, detailed in Table- 2 and explained in the preceding paragraphs, appears to be a good model in spite of certain weaknesses. It performed best among several specifications tried, both in terms of the usual diagnostic statistics and economic theory. However, this estimated model still needs to go through at least three major modifications. First, its first wheat acreage equation is an autoregressive function, which yields short-run results; it needs to be converted into a long-run version. Second, its second equation contains the predicted value of area $(\hat{A})$, which is estimated in the first equation; hence, $\hat{A}$ in the second equation will have to be replaced with its estimated value. Third, the model contains an import supply $\left(\mathrm{I}_{s}\right)$ function but lacks an import demand $\left(\mathrm{I}_{\mathrm{d}}\right)$ function to be computed as per the identity equation $I_{d}=D_{d}-S_{d}$.

To convert the first equation from its short run to a long run version, we first need to compute the coefficient of adjustment $(\lambda)$, and then adjust the short-run equation to its long-run version. In the short-run equation, the value of the estimated coefficient on the lagged dependent variable $A_{t-1}$ is 0.48947 , which is equal to $1-\lambda$. Hence, solving for $\lambda$ :

$$
\begin{aligned}
\lambda & =1-0.48947 \\
& =0.51053
\end{aligned}
$$

To convert the short-run wheat acreage equation into its long-run version, we need to divide all coefficients attached to explanatory variables and constant by the value of $(\lambda)$ and omit the lagged variable from the equation. By doing so, we get the long-run version of the wheat acreage equation:

$$
A=7176.9189+48.93934 T R
$$

Since the estimated domestic wheat supply equation includes the predicted value of variable ' $A$ ', which we have now estimated in equation (3), we substitute equation (3) into the former equation, allowing the domestic wheat supply equation to take the following form:

$\mathrm{S}_{\mathrm{d}}=-8458.219+2.4879(7176.919+48.9393 \mathrm{TR})+0.41528 \mathrm{P}_{\mathrm{d}}+2.4625$

FNTW $=9397.238+0.41528 \mathrm{P}_{d}+2.4625 \mathrm{FNTWT}+121.7562 \mathrm{TR}$ 
We can remove variable TR by putting in its average value, multiplying with the estimated coefficient and adding the resultant figure to the intercept.

$$
\mathrm{S}_{\mathrm{d}}=11040.9577+0.41528 \mathrm{P}_{\mathrm{d}}+2.4625 \mathrm{FNTWT}
$$

By the same procedure, we can remove the variable FNTW'T and further condense the domestic supply equation.

$$
\mathrm{S}_{\mathrm{d}}=13485.77+0.41528 \mathrm{P}_{\mathrm{d}}
$$

Similarly, the domestic wheat demand $\left(D_{d}\right)$ function can be further condensed as follows.

$$
\begin{aligned}
\mathrm{D}_{\mathrm{d}} & =750.129-0.046974 \mathrm{P}_{\mathrm{d}}+136.07 \mathrm{POP} \\
& =16896.20-0.046974 \mathrm{P}_{\mathrm{d}}
\end{aligned}
$$

The estimated model lacks an import demand $\left(I_{d}\right)$ function, which is computed as an identity equation (difference between $D_{d}$ and $S_{d}$ ); hence:

$$
\begin{aligned}
I_{d} & =D_{d}-S_{d} \\
& =\left(16896.20-0.046974 P_{d}\right)-\left(13485.77+0.41528 P_{d}\right) \\
& =3410.43-0.462254 P_{d}
\end{aligned}
$$

The estimated wheat import price equation and wheat import supply equation, respectively, represent the effect of the world wheat trade price $\left(\mathrm{P}_{\mathrm{w}}\right)$ on Pakistan's wheat import/trade price $\left(\mathrm{P}_{\mathrm{i}}\right)$ and shows how Pakistan's wheat import supply $\left(\mathrm{I}_{\mathrm{s}}\right)$ is affected by its various determinants.

$\mathrm{P}_{\mathrm{i}}=23.1559+0.91124 \mathrm{P}_{\mathrm{w}}$

$I_{s}=-5642.2+5.2191 P^{\wedge}-0.96151 S_{d, t-1}+0.68329 D_{d, t-1}+0.017019 S_{w}$

We can merge equation (7) with equation (8a) to create equation (8b).

$I_{s}=-5521.1413+4.7556 P_{w}-0.96151 S_{d, t-1}+0.68329 D_{d, t-1}+0.017019 S_{w}$

Replacing the average values of variables $S_{d, t-1}$ and $D_{d, t-1}$ and adding the intercept, we get a shortened version of the equation:

$I_{s}=-8922.5358+4.7556 P_{w}+0.017019 S_{w}$ 
We can further condense the equation by replacing the average values of variable $S_{w}$.

$I_{s}=389.5862+4.7556 P_{w}$

\section{Final Easy-to-Use Model}

What has been computed and presented in equations (4) through (8) represents a full model of Pakistan's wheat crop sector. This model provides two equations for both the domestic wheat supply (4b and 4c) and domestic demand $(5 \mathrm{a}$ and $5 \mathrm{~b})$. It further consists of one equation each for wheat import demand (6c) and wheat import price as it influenced by the world wheat price (7), and three equations for wheat export supply to Pakistan (8b-d). Table-3 presents a summarized version of this easy-to-use model of Pakistan's wheat supply and demand functions.

\section{Conclusion and Recommendations}

\section{Conclusion}

It appears that Pakistan's domestic wheat supply is not only priceresponsive but also positively affected by the use of nutrient fertilizers. Policymakers need to take note of these factors.

While price appears to be a statistically significant factor on the supply side, it is a statistically insignificant factor on the demand side, while population size appears to be very significant in determining the total demand for wheat in Pakistan. These results portray the ground realities of Pakistan where wheat constitutes an essential sizeable proportion of the average person's daily diet.

Wheat import supply to Pakistan seems to be influenced by the current world wheat price, current world wheat supplies, domestic previous years' consumption, and domestic previous years' supply. The first three variables positively affect wheat import supply to Pakistan, while the last variable negatively affects it.

\section{Recommendations}

On one hand, Pakistani wheat growers are found to respond positively to wheat prices, while on the other hand, the incoming W'TO regime has asked the government to abandon the announcement of support prices. It is therefore recommended that public and private sector policymakers formulate a policy that allows market forces to play a role in the wheat 
economy such that the wheat producers do not suffer due to adverse market conditions.

Besides price, the use of nutrient fertilizers seems to play a positive role in determining wheat supply. Therefore, the supply of various nutrient fertilizers, their availability at appropriate times and easy-to-reach places and their use on crops in recommended amounts should be major measures under the government's future inputs use policy.

It is further recommended that policymakers and researchers work on other food alternatives so that Pakistan's dependence on wheat is eased as far as possible.

\section{Table-1: Definitions of Variables and their Mean Values}

Name of Variable

$\mathrm{A}=$ area under wheat in '000' hectares

$\hat{\mathrm{A}}=$ area predicted in ' 000 ' hectares

$\mathrm{A}_{\mathrm{t}-1}=$ lagged area in '000' hectares

$\mathrm{S}_{\mathrm{d}}=$ domestic supply in '000' tons

$\mathrm{S}_{\mathrm{d}, \mathrm{t}-1}=$ lagged domestic supply in '000' tons

$\mathrm{D}_{\mathrm{d}}=$ domestic demand in ' 000 ' tons

$\mathrm{D}_{\mathrm{d}, \mathrm{t}-1}$ lagged domestic demand in '000' tons

$\mathrm{S}_{\mathrm{w}}=$ world supply of wheat in '000' tons

$I_{s}=$ Net import in '000' tons

$\mathrm{P}_{\mathrm{d}}=$ domestic price in Pak. Rupees per $\mathrm{m}$. ton.

$P_{\mathrm{i}}=$ Pakistan level trade price per ton in US\$

$\mathrm{P}_{\mathrm{w}}=$ world level trade price per ton in US\$

FNTWT, nutrient-fertilizers used in wheat in '000' tons

POT $=$ population of Pakistan in millions

$\mathrm{TR}=$ trend variable for the years of observations included

\section{Mean Value}

7837.60

7837.60

7774.00

15512.00

15099.00

16667.00

16269.00

547170.00

1154.60

4879.20

169.82

160.95

992.82

118.66 
Table-2: Empirical Results of Estimated Econometrics Model

\begin{tabular}{|c|c|c|c|c|c|c|}
\hline \multicolumn{7}{|c|}{ Wheat Acreage Equation } \\
\hline Variable & Coefficient & t-Ratio & p-Value & $\mathbf{R}^{2}$ & $\mathbf{F}$ & $\begin{array}{c}\text { DW/ } \\
\text { Durban h }\end{array}$ \\
\hline Intercept & 3695.163 & 3.093 & 0.005 & \multirow{3}{*}{0.8473} & \multirow{3}{*}{\multicolumn{2}{|c|}{$\begin{array}{c}\mathrm{DW}=2.3969 \\
9 \quad \text { Durban h } \\
=-2.0996\end{array}$}} \\
\hline$A_{t-1}$ & 0.48947 & 2.864 & 0.009 & & & \\
\hline TR & 24.985 & 2.223 & 0.036 & & & \\
\hline \multicolumn{7}{|c|}{ Wheat Domestic Supply Equation } \\
\hline Variable & Coefficient & t-Ratio & p-Value & $\mathbf{R}^{2}$ & $\mathbf{F}$ & DW \\
\hline Intercept & -8458.219 & -1.162 & 0.2580 & \multirow{4}{*}{0.9252} & \multirow{4}{*}{90.685} & \multirow{4}{*}{2.5064} \\
\hline$\hat{\mathrm{A}}$ & 2.4879 & 2.357 & 0.028 & & & \\
\hline$P_{d}$ & 0.41528 & 2.308 & 0.031 & & & \\
\hline FNTWT & 2.4625 & 1.310 & 0.204 & & & \\
\hline \multicolumn{7}{|c|}{ Wheat Domestic Demand Equation } \\
\hline Variable & Coefficient & t-Ratio & p-Value & $\mathbf{R}^{2}$ & $\mathbf{F}$ & DW \\
\hline Intercept & 750.129 & 0.188 & 0.853 & \multirow{3}{*}{0.7737} & & \multirow{3}{*}{1.1857} \\
\hline$P_{d}$ & -0.04697 & -0.1349 & 0.8940 & & 39.313 & \\
\hline POP & 136.07 & 2.905 & 0.008 & & & \\
\hline \multicolumn{7}{|c|}{ Wheat Import Price Equation } \\
\hline Variable & Coefficient & t-Ratio & p-Value & $\mathbf{R}^{2}$ & $\mathbf{F}$ & DW \\
\hline Intercept & 23.1559 & 0.8080 & 0.4270 & \multirow{2}{*}{0.5269} & \multirow{2}{*}{26.734} & \multirow{2}{*}{1.6565} \\
\hline$\underline{P_{w}}$ & 0.91124 & 5.170 & 0.000 & & & \\
\hline \multicolumn{7}{|c|}{ Wheat Import Supply Equation } \\
\hline Variable & Coefficient & t-Ratio & p-Value & $\mathbf{R}^{2}$ & $\mathbf{F}$ & DW \\
\hline Intercept & -5642.2 & -2.483 & 0.022 & & & \\
\hline $\mathbf{P}_{i}^{\wedge}$ & 5.2191 & 0.7298 & 0.4740 & & & \\
\hline $\mathrm{S}_{\mathrm{d}, \mathrm{t}-1}$ & -0.96151 & -6.174 & 0.000 & 0.6666 & 10.498 & 2.2496 \\
\hline $\mathrm{D}_{\mathrm{d}, \mathrm{t}-1}$ & 0.68329 & 5.109 & 0.000 & & & \\
\hline $\mathrm{S}_{\mathrm{w}}$ & 0.017019 & 3.130 & 0.005 & & & \\
\hline
\end{tabular}


Table-3: The Final Easy-To-Use Wheat Supply and Demand Model

Wheat Domestic Supply Equation

\begin{tabular}{|c|c|c|c|}
\hline Variable & Full Equation-1 & \multicolumn{2}{|c|}{ Shortened Equation-2 } \\
\hline Intercept & 11040.9577 & \multicolumn{2}{|c|}{13485.77} \\
\hline$P_{d}$ & 0.41528 & \multicolumn{2}{|c|}{0.41528} \\
\hline FNTWT & \multicolumn{3}{|c|}{ FNTW'T } \\
\hline \multicolumn{4}{|c|}{ Wheat Domestic Demand Equation } \\
\hline Variable & Full Equation-1 & \multicolumn{2}{|c|}{ Shortened Equation-2 } \\
\hline Intercept & 750.129 & \multicolumn{2}{|c|}{16896.20} \\
\hline$P_{d}$ & -0.046974 & \multicolumn{2}{|c|}{-0.046974} \\
\hline POP & 136.07 & & \\
\hline \multicolumn{4}{|c|}{ Wheat Import Demand Equation } \\
\hline Variable & Coefficient & & \\
\hline Intercept & 3410.43 & & \\
\hline $\mathrm{P}_{\mathrm{d}}$ & -0.462254 & & \\
\hline \multicolumn{4}{|c|}{ Wheat Import Price Equation } \\
\hline Variable & Coefficient & & \\
\hline Intercept & 23.1559 & & \\
\hline$\underline{P_{w}}$ & 0.91124 & & \\
\hline \multicolumn{4}{|c|}{ Wheat Import Supply Equation } \\
\hline Variable & Full Equation-1 & $\begin{array}{c}\text { Shortened } \\
\text { Equation-2 }\end{array}$ & $\begin{array}{r}\text { Shortened } \\
\text { Equation-3 } \\
\end{array}$ \\
\hline Intercept & -5521.1413 & -8922.5358 & 389.5862 \\
\hline$P_{w}$ & 4.7556 & 4.7556 & 4.7556 \\
\hline $\mathrm{S}_{\mathrm{d}, \mathrm{t}-1}$ & -0.96151 & & \\
\hline $\mathrm{D}_{\mathrm{d}, \mathrm{t}-1}$ & 0.68329 & & \\
\hline $\mathrm{S}_{\mathrm{w}}$ & 0.017019 & 0.017019 & \\
\hline
\end{tabular}




\section{References}

Ahmad, B., and Chaudary, A.M. (1987). Profitability of Pakistan's Agriculture. In Azhar, B.A. (ed.) (1996). Pakistan Agricultural Economics - A Book of Readings. National Book Foundation, Islamabad.

Alderman, H. (1988). Estimates of Consumer Price Response in Pakistan Using Market Prices as Data. The Pakistan Development Review. Pakistan Institute of Development Economics 27(2), 89-107.

Ali, M. (1988). Supply Response of Major Crops in Pakistan: A Simultaneous Equation Approach. Special Report Series \# 11. Pakistan Economic Analysis Project, Ministry of Food and Agriculture, Islamabad.

Arifullah, S. (2007). Pakistan's Crop Sector: An Economic Analysis. PhD Thesis, Department of Agricultural Economics, NWFP Agricultural University Peshawar-Pakistan.

Ashfaq, M., Griffith, G., and Parton, K. (2001). Welfare Effects of Government Interventions in the Wheat Economy of Pakistan. Pakistan Journal of Agricultural Economics. Agricultural Prices Commission, 4(1), 25-33.

Cornelisse, P. and Kuijpers, B. (1987). A policy model of the wheat and rice economy of Pakistan. Pakistan Development Review 25(4): 365-399.

Cumming, J.T. (1975). Cultivator Responsiveness in Pakistan - Cereal and Cash Crops. Pakistan Development Review, 14, 261-73.

Falcon, W.P. (1964). Farmer Response to Price in a Subsistence Economy: The Case of West Pakistan. The American Economic Review, 54, 580-591.

FAO Database. www.fao.org.

GoP (Various Issues). Agricultural Statistics of Pakistan. Ministry of Food, Agriculture \& Livestock: Islamabad.

Gujarati, N.D. (2003). Basic Econometrics. Fourth Edition. McGraw Hill, New York: USA. 
Hamid, N., Pinckney, T., Gnaegy, S., and Valdes, S. (1987). The Wheat Economy of Pakistan: Setting and Prospects (mimeograph). USAID/International Food Policy Research Institute, Washington D.C.

Maddala, G.S. (2002). Introduction to Econometrics. Third Edition. John Wiley \& Sons, Ltd: New York.

Tweeten, L. (1986). Supply Response in Pakistan. Department of Agricultural Economics, Oklahoma State University, Agriculture Policy Analysis Project's Report USAID, Washington DC.

Zulfiqar, M. (2008). WTO's Trade Liberalization: Implications for Pakistan's Crop Sector. PhD Thesis. Dept. of Agric. Econ. NWFP Agric. Univ. Peshawar, Pakistan. 